\title{
PENGARUH PRINSIP GOVERNANCE DALAM PERENCANAN TATA RUANG DI KOTA METRO PROVINSI LAMPUNG
}

\author{
Bambang Utoyo S. \\ Jurusan Ilmu Administrasi Negara FISIP Universitas Lampung \\ Jl. Prof. Dr. Sumantri Brojonegoro 1 Bandar Lampung \\ Email: bus6263@gmail.com
}

\begin{abstract}
Perencanaan tata ruang kota sebagai bentuk intervensi kebijakan secara spasial dalam manajemen pembangunan perkotaan berdasarkan perpektif governance tidak saja menuntut kerterlibatan multi aktor/ agensi, akan tetapi juga mensyaratkan diterapkannya prinsip-prinsip governance dalam upaya mewujudkan good urban governanace. Sedangkan tujuan yang akan dicapai dalam penelitian ini meliputi: mendeskripsikan dan menganalisis pengaruh penerapan prinsip-prinsip governance terhadap perencanaan tata ruang wilayah kota. Metode penelitian menggunakan analisis kuantitatif berdasarkan metode survai terhadap aktor pemerintah kota; civil society/masyarakat; dan sektor bisnis berdasarkan teknik proporsional random sampling. Adapun model analisisnya menggunakan analisis regresi. Hasil penelitian menunjukkan, bahwa prinsip governance yang meliputi: akuntabilitas, transparansi, responsif dan partisipasi yang secara statistik berpengaruh secara nyata dan signifikan dalam perencanaan tata ruang kota dengan formulasi model $\mathrm{Y}=-3.866+0.580 \mathrm{X}_{1}-0.144 \mathrm{X}_{2}+1.196$ $\mathrm{X}_{3}+0.820 \mathrm{X}_{4}+$ e. Dengan demikian, dapat dijelaskan, bahwa jika tidak ada akuntabilitas, transparansi, responsif dan partisipasi dalam perencanaan tata ruang kota, maka rencana tata ruang kota yang dihasilkan adalah -3.866 . Penambahan 1 unit akuntabilitas akan meningkatkan bobot perencanaan tata ruang kota sebesar 0.580 . Setiap pengurangan 1 unit transparansi akan mengurangi bobot perencanaan tata ruang kota sebesar - 0.144. Setiap penambahan 1 unit responsibilitas akan meningkatkan bobot perencanaan tata ruang kota sebesar 1.196. Dan setiap penambahan 1 unit partisipasi akan meningkatkan bobot perencanaan tata ruang kota sebesar 0.820 . Model regresi yang dihasilkan dapat digunakan sebagai prediktor perencanaan tata ruang kota daripada rata-rata perencanaan tata ruang kota itu sendiri. Adapun saran dan implikasi kebijakan yang dapat direkomendasikan adalah, bahwa penerapan prinsip governance harus menjadi mindset para aparatur publik dalam mengatasi berbagai kepentingan dan persoalan publik di wilayah perkotaan. Selain itu dibutuhkan berbagai insentif kebijakan bagi operasionalisasi prinsip governance dalam mewujudkan good urban governance.
\end{abstract}

Kata kunci: Perencanaan kota; Governance; Prinsip governance

\section{GOVERNANCE PRINCIPAL ON SPATIAL PLANNING IN METRO MUNICIPALITY LAMPUNG PROVINCE}

\begin{abstract}
In the formulation of the spatial planning policy as the main prerequisite for the urban development implementation, based on the governance perspective have required all the actor/agent of development to be involved in it based on the governance principals in order to fulfil the good urban governance. This research was conducted to described and analysed the influence of governance principals in the urban planning preparation. The research method used in answering the research objectives was conducted through method of surveying the actors/agent involved in the urban planning preparation which subsequently analysed quantitatively by using a regression analysis model. The research result showed, that accountability, transparency, responsiveness and participation principles have significant relationship on urban planning. The resulted regression model can be used to predict urban planning, in which accountability, transparency, responsiveness and participation simultaneously influence urban planning. The model of urban planning resulted based on the governance perspective is $Y=-3.866$ +0.580 accountability -0.144 transparency +1.196 responsiveness +0.820 participation + e. It was supported by the regression analysis result that showed, that if there were no accountability, transparency, responsiveness and participation in the urban planning preparation, the urban planning preparation produced was -3.866 . With every addition of 1 unit of accountability will increase the weight of urban planning of 0.580 . Every decrease of 1 unit transparency will decrease the weight of urban planing of - 0.144. Every addition of 1 unit of responsibility will increase the weight of urban planning of 1.196. And every addition of 1 unit of participation will increase the weight of urban planning of 0.820 . Thus, the suggestion recommended was, governance principles must be concidered to be the mindset of public servants in doing the public interest and public affairs, especially on spatial planning. Moreover, a policy incentive is needed for the operationalization of governence principal to fulfil the good urban governance.
\end{abstract}

Keywords: Urban planning, Governance; Governance principals

\section{PENDAHULUAN}

Wilayah perkotaan dewasa ini telah menunjukan perkembangan yang sangat pesat sejalan dengan pembangunan di Indonesia pada umumnya. Hal ini tidak terlepas dari kenyataan bahwa perkotaan adalah lokasi yang paling effisien dan effektif untuk kegiatankegitan produktif sehubungan dengan ketersediaan sarana dan prasarana, tersedianya tenaga trampil, tersedianya dana sebagai modal dan sebagainya. Tidak berlebihan kalau dikatakan bahwa perkotaan 
memiliki nilai strategis. Perkotaan tidak sekedar sebagai pemusatan penduduk serta berbagai fungsi sosial-ekonomi-politik dan administrasi, tetapi juga potensial sebagai instrumen untuk mencapai tujuantujuan pembangunan pada tingkat regional maupun nasional. Kawasan perkotaan akan semakin penting peranannya baik sebagai simpul kegiatan pelayanan dan pusat kegiatan produksi dan distribusi, pusat industri, pusat jasa dan keuangan, serta pusat pelayanan umum maupun sebagai pusat inovasi dan kemajuan sosial budaya

Pertumbuhan dan perkembangan yang yang terjadi di wilayah perkotaan tersebut pada gilirannya juga diikuti dengan tekanan-tekanan (urban development pressures) yang merupakan implikasi dari tingginya tingkat pertumbuhan penduduk terutama akibat arus urbanisasi (lihat: United Nation, 2000; Dardak, 2006; Marshall, 2007) sehingga menyebabkan pengelolaan ruang kota makin berat. Permasalahan tersebut diantaranya: beralih fungsinya lahan-lahan pertanian yang subur di sekitar kota-kota menjadi lahan-lahan non pertanian; makin kritisnya cadangan air tanah dan air permukaan; meningkatnya inefisiensi dalam pelayanan prasarana dan sarana perkotaan karena wilayah perkotaan yang makin melebar ke segala arah; serta berkurangnya tingkat produktivitas masyarakat perkotaan yang diakibatkan oleh makin besarnya tenaga dan waktu yang terbuang untuk mencapai pusat-pusat kegiatan (Kartasasmita, 1997).

Oleh karena itu untuk mengantisipasi berbagai persoalan tersebut diperlukan manajemen pembangunan perkotaan yang handal melalui instrumen kebijakan yang tepat. Hal tersebut, tentunya tidak akan dapat terlaksana tanpa adanya penataan ruang sebagai salah satu bentuk kebijakan publik dalam pengelolaan pembangunan perkotaan dilihat dari aspek spasial. Penataan ruang adalah suatu sistem proses perencanaan tata ruang, pemanfaatan ruang, dan pengendalian pemanfaatan ruang (UU No.26 Th 2007). Ketersediaan rencana tata ruang wilayah sebagai hasil dari perencanaan tata ruang adalah prasyarat utama bagi penyelenggaraan pembangunan wilayah, mengingat rencana tata ruang wilayah menjadi acuan dasar didalam penyelenggaraan pembangunan setiap sektor pengisi ruang kota tersebut. Proses perencanaan tata ruang wilayah, yang menghasilkan rencana tata ruang wilayah (RTRW). Disamping sebagai "guidance of future actions" RT RW pada dasarnya merupakan bentuk intervensi yang dilakukan agar interaksi manusia/makhluk hidup dengan lingkungannya dapat berjalan serasi, selaras, seimbang untuk tercapainya kesejahteraan manusia/makhluk hidup serta kelestarian lingkungan dan keberlanjutan pembangunan (development sustainability).

Perencanaan tata ruang sebagai salah bagian dalam aktivitas penataan ruang sesungguhnya merupakan bentuk formulasi kebijakan publik yang terkait dengan dengan pengelolaan ruang kota. Dalam sebuah proses perencanaan, akan sangat terkait sekali dengan proses penentuan pilihan-pilihan yang merupakan pengejawentahan dari proses politik yang terjadi dalam proses perumusan kebijakan publik. Sehingga setiap aktivitas yang ada di dalamnya merupakan sebuah usaha yang dilakukan memiliki titik fokus untuk mencapai sebuah kondisi keruangan dalam konteks problem solving, future oriented dan resource allocation. John Friedman (1987), memberikan definisi lebih luas mengenai planning sebagai upaya menjembatani pengetahuan ilmiah dan teknik (scientific and technical knowldge) kepada tindakan-tindakan dalam domain publik, menyangkut proses pengarahan sosial dan proses transformasi sosial. Dalam kerangka perencanaan dipandang sebagai sebuah alat dan metode dalam pengambilan keputusan dan tidakan publik, maka sudah sewajarnya dipahami akan adanya dimensi politik dalam perencanaan. Tindakan-tindakan yang dilakukan oleh pelaku kebijakan dalam proses perumusan kebijakan publik akan sangat ditentukan oleh perspektif yang digunakan. Dalam perspektif governance sebagai salah satu perspektif alternatif dalam proses formulasi kebijakan publik sesungguhnya merupakan mekanisme pengelolaan sumber daya ekonomi dan sosial yang melibatkan pengaruh sector negara dan sector non-pemerintah dalam suatu usaha kolektif. Definisi ini mengasumsikan banyak aktor yang terlibat dimana tidak ada yang sangat dominan yang menentukan gerak aktor lain. Pesan pertama dari terminologi governance membantah pemahaman formal tentang bekerjanya institusi-institusi negara. Governance mengakui bahwa didalam masyarakat terdapat banyak pusat pengambilan keputusan yang bekerja pada tingkat yang berbeda.

Implementasi governance bagi terwujudnya tujuan-tujuan pembangunanyang termanifestasi dalam perencanaan tata ruang (Akil, 2001), sudah barang tentu menuntut diterapkannya prinsip-prinsip yang melekat dalam gagasan governance itu sendiri (lihat: Bovaird dan Loffler, 2003; Enserink and Koppenjan, 2007; LAN, 2000). Penerapan prinsip-prinsip tersebut dimaksudkan agar proses dan pencapaian tujuan (tata kelola) dapat terselenggara secara efektif dan efisien dalam mengatasi berbagai persoalan yang dihadapi oleh masyarakat. Sebab, sebagaimana diketahui bahwa administrasi public sangat perhatian terhadap terwujudnya tata kepemerintahan yang baik dan amanah. Tata kepemerintahan yang baik (good governance) itu diwujudkan dengan lahirnya tatanan kepemerintahan yang demokratis dan diselenggarakan secara baik, bersih, transparan dan dan berwibawa (Thoha, 2008). Selain itu, good governance juga mendorong demokratisasi dengan cara memaksa negara untuk berbagi kekuasaan dengan aktor-aktor di luar negara (Pratikno, 2005), yang ditandai oleh beberapa karakter, seperti: transparansi, partisipasi, representasi, akuntabilitas dan penegakan hak azasi manusia. Selanjutnya, menurut Minogue, Polidano \& Hulme dalam Islamy (2003), dikemukakan bahwa penyelenggaraan pemerintahan yang baik itu ditujukan untuk mencapai lebih dari sekedar pengelolaan sumber-sumber ekonomi dan finansial yang lebih efisien; tetapi ini juga merupakan suatu strategi 
reformasi yang lebih luas untuk memperkuat lembagalembaga masyarakat sipil dan upaya menjadikan pemerintahan itu lebih terbuka (transparan), responsif, akuntabel dan demokratis. Demikian pula halnya Suzzeta (2006), yang mengemukakan, bahwa good governance memiliki banyak prinsip atau dapat juga di sebut nilai-nilai (values), empat di antaranya yang utama adalah transparasi (transparency), partisipasi (participation), ketaatan pada aturan hukum (rule of law) dan akuntabilitas (accountability).

Perencanaan tata ruang cenderung masih banyak diwarnai oleh "kepentingan publik terbatas". Oleh karena itu pada tataran implementasinya seringkali menyisakan berbagai persoalan dan dampak yang muncul sebagai akibat dari lemahnya perencanaan itu sendiri. Proses pengambilan keputusan publik secara demokratis berdasarkan god governance merupakan suatu proses yang sangat kondusif terhadap konsep perencanaan (tata ruang kota) sebagai sebuah proses pembelajaran sosial, dimana peran masyarakat (termasuk di dalamnya civil society dan privat sektor) sebagai stakeholder menjadi sangat diperhatikan dibandingkan dengan proses pengambilan keputusan yang dilakukan pada pola rasional semata. Oleh karenanya, menjadi sangat relevan dan penting kajian terhadap penyusunan rencana tata ruang kota dilakukan atas dasar good governance melalui penerapan prinsip-prinsip yang melekat di dalamnya. Tulisan ini dimaksudkan untuk mendeskripsikan dan menganalisis pengaruh prinsip good governance terhadap perencanaan tata ruang kota dalam mewujudkan kota yang demokratis, produktif, nyaman dan berkelanjutan.

\section{METODE}

Metode yang digunakan dalam penelitian ini menggunakan pendekatan kuantitatif. Data diperoleh melalui survai terhadap 100 responden yang dilakukan secara proporsional random sampling terhadap aktor yang terlibat dalam penyusunan rencana tata ruang kota, yaitu aktor pemerintah kota; civil society/ masyarakat; dan sektor swasta. Analisis data dilakukan dengan menggunakan model analisis regresi linier berganda (Algifari; 2000), dengan formulasi sebagai berikut:

$$
\begin{aligned}
& \hat{Y}=a+b_{1} X_{1}+b_{2} X_{2}+\ldots \ldots+b_{n} X_{n} \\
& \text { Keterangan: } \\
& \square=\text { nilai estimasi } Y \\
& a=\text { nilai } Y \text { pada perpotongan antara garis linear } \\
& \text { dengan sumbu vertikal } Y \\
& X_{1}, X_{2}, . . X_{n}=\text { nilai variabel independen } X_{1}, X_{2}, \\
& . . X_{n} \\
& b_{1}, b_{2}, . . b_{3},=\text { slope yang berhubungan dengan } \\
& \text { variabel } X_{1}, X_{2}, . . X_{n}
\end{aligned}
$$

\section{HASIL DAN PEMBAHASAN}

Untuk mengetahui pengaruh penerapan prinsip governance dalam perencanaan tata ruang kota, data diperoleh melalui metode survai terhadap terhadap sampel penelitian yang dilakukan degan menggunakan teknik proportional random sampling dari unsur pemerintah kota; masyarakat dan sektor bisnis. Selanjutnya data tersebut, dianalisis secara kuantitatif dengan menggunakan model analisis regresi berganda. Adapun deskripsi responden penelitian, dapat diketahui pada tabel berikut ini. Tabel 1. Klasifikasi Responden Penelitian

\begin{tabular}{clcc}
\hline No & Klasifikasi Aktor/ Agensi & Jumlah & Persentase \\
\hline 1 & Pemerintah Kota Metro & 46 & $46 \%$ \\
2 & Masyarakat (Civil Society) & 42 & $42 \%$ \\
3 & Sektor Swasta (Bisnis) & 12 & $12 \%$ \\
& Jumlah & 100 & $100 \%$ \\
\hline
\end{tabular}

Sumber: Data Penelitian

Responden yang berasal dari unsur pemerintah kota berasal dari dinas/ instansi yang terkait dengan aktivitas perencanaan tata ruang, diantaranya adalah Bappeda, Dinas Tata Kota dan Lingkungan Hidup, Dinas Pekerjaan Umum, Dinas Perhubungan, Dinas Pertanian, Dinas Koperasi, Industri dan Perdagangan (Koperindag), Staf Ahli Walikota, Bagian pemerintahan, perekonomian dan pembangunan di lingkungan Sekretariat Kota termasuk didalamnya adalah unsur camat dan kepala kelurahan yaitu 2 orang camat dan 9 orang lurah. Termasuk dalam kelompok ini adalah anggota DPRD yang mewaki unsur pimpinan dan komisi yang membidangi masalah tata ruang sebanyak 5 orang. Adapun responden yang berasal dari unsur masyarakat terdiri atas lembaga swadaya masyarakat (LSM), ketua LPM (Lembaga Pemberdayaan Masyarakat), pimpinan organisasi sosial kemasyarakatan, tokoh masyarakat, pers (wartawan), dosen (akademisi) dan pimpinan organisasi mahasiswa. Sedangkan responden dari sektor swasta meliputi unsur pengembang (developer), KADIN, pengusaha retail, perbankan, kontraktor, perwakilan pedagang kaki lima, organda (pengusaha transportasi) dan konsultan perencana.

Berdasarkan hasil penelitian diketahui, bahwa nilai rata-rata (mean) dan standar deviasi (standard deviation) masing-masing variabel penelitian dapat diketahui pada tabel berikut ini.

Tabel 2. Tabel Nilai Standar Deviasi dan rata-Rata

\begin{tabular}{lccc}
\hline \multicolumn{4}{c}{ Descriptive Statistics } \\
\hline & Mean & Std. Deviation & $\mathrm{N}$ \\
Perencanaan TRK (Y1) & 57.16 & 9.102 & 100 \\
Akuntabilitas (X1) & 25.97 & 2.592 & 100 \\
Transparansi (X2) & 25.74 & 3.700 & 100 \\
Responsif (X3) & 24.65 & 3.523 & 100 \\
Partisipasi (X4) & 24.62 & 4.158 & 100 \\
\hline
\end{tabular}

Sumber: Hasil Analisis

Dari tabel diatas dapat diketahui bahwa nilai rata-rata jawaban responden maupun standar deviasi atas masing-masing variabel penelitian. Melalui penggunaan Standard Error of Mean selanjutnya dapat diperkirakan besar rata-rata populasi yang diperkirakan dari sampel yang dalam penelitian ini menggunakan tingkat kepercayaan 95\%. Artinya, jika diketahui nilai rata-rata persepsi sampel (responden penelitian) terhadap masing-masing variabel, maka dapat diperkirakan diperkirakan nilai persepsi 
populasi (semua orang di Kota Metro) terhadap masing-masing variabel dalam perencanaan tata ruang kota dengan kemungkinan kesalahan sebesar $5 \%$ dalam generalisasi data diatas.

Hasil penelitian, juga menunjukkan, bahwa besar hubungan antara antara variabel bebas yang meliputi variabel akuntabilitas (X1), variabel transparansi (X2), variabel responsif (X3), dan variabel partisipasi (X4) dengan variabel terikat yaitu variabel perencanaan tata ruang kota (Y1) nilainya masing-masing sebesar 0.586; 0.638 ; 0.847; dan 0.829. Berdasarkan nilai korelasi tersebut, secara teoritis dapat dikemukakan, bahwa variabel partisipasi dan responsif lebih berpengaruh terhadap perencanaan tata ruang kota dibandingkan dengan variabel akuntabilitas dan transparansi. Selain itu berdasarkan hasil analisis juga diketahui, bahwa terdapat multikolinearitas atau korelasi diantara variabel bebas yaitu variabel responsif dan partisipasi yang tercermin dari nilai korelasi yang cukup kuat diantara keduanya yaitu 0.887 .

Tingkat signifikansi koefisien korelasi satu sisi dari output (diukur dari probabilitas) menghasilkan angka 0.000 atau praktis 0 . Oleh karena probabilitas jauh dibawah 0.05 , maka korelasi diantara variabel perencanan tata ruang dengan akuntabilitas, transparansi, responsif dan partisipasi sangat nyata. Angka R square yang didapatkan dari hasil perhitungan adalah 0.762, hal ini mengandung makna bahwa $76,2 \%$ dari variasi perencanaan tata ruang kota bisa dijelaskan oleh variabel akuntabilitas, transparansi, responsif dan partisipasi. Sedangkan sisanya, yaitu 23,8\% dijelaskan oleh sebab-sebab yang lain. Tabel di bawah ini menjelaskan hal tersebut. Tabel 3. Tabel Nilai R dan R Square

\begin{tabular}{ccccc}
\hline \multicolumn{4}{c}{ Model Summary $^{\mathrm{b}}$} \\
\hline Model & $\mathrm{R}$ & R Square & Adjusted R Square & Std. Error of the Estimate \\
1 & $.873^{\mathrm{a}}$ & .762 & .752 & 4.534 \\
\multicolumn{4}{c}{ a. Predictors: (Constant), Partisipasi (X4), Akuntabilitas (X1), Transparansi (X2), Responsif (X3) } \\
b. Dependent Variable: Perencanaan TRK (Y1)
\end{tabular}

Standard Error of Estimate diperoleh angka 4.534 atau 4.5 unit, yang apabila dikaitkan dengan standar deviasi perencanaan tata ruang kota yang nilainya 9.102, yang jauh lebih besar dari standar error of estimate yang hanya 4.534. Oleh karena lebih kecil dari nilai standar deviasi perencanaan tata ruang kota, maka model regresi lebih bagus dalam bertindak sebagai prediktor perencanaan tata ruang kota daripada rata-rata perencanaan tata ruang kota itu sendiri. Lebih lanjut dari hasil analisis diketahui, bahwa dari uji ANOVA atau $\mathrm{F}$ test, didapatkan $\mathrm{F}$ hitung adalah 76.010 dengan tingkat signifikansi 0.000 . Karena probabilitas $(0.000)$ jauh lebih kecil dari 0.05 , maka model regresi dapat dipakai untuk memprediksi perencanaan tata ruang kota. Atau bisa dikatakan bahwa, akuntabilitas, transparansi, responsif dan partisipasi secara bersama-sama berpengaruh terhadap perencanaan tata ruang wilayah kota. Secara jelas hal tersebut dapat dilihat pada tabel berikut ini.

Tabel 4. Tabel Nilai F

\begin{tabular}{llccccc}
\hline \multicolumn{6}{c}{ ANOVA $^{\mathrm{b}}$} \\
\hline \multicolumn{1}{c}{ Mode1 } & $\begin{array}{c}\text { Sum of } \\
\text { Squares }\end{array}$ & df & $\begin{array}{c}\text { Mean } \\
\text { Square }\end{array}$ & F & Sig. \\
& Regression & 6.248 .909 & 4 & 1.562 .227 & 76.010 & .000 \\
1 & Residual & 1.952 .531 & 95 & 20.553 & & \\
Total & 8.201 .440 & 99 & & &
\end{tabular}

a. Predictors: (Constant), Partisipasi (X4), Akuntabilitas (X1),

Transparansi (X2), Responsif (X3)

b. Dependent Variable: Perencanaan TRK

(Y1)

Tabel 5. Tabel Nilai Koefisien Regresi

\begin{tabular}{ccccccc}
\hline Model & \multicolumn{2}{c}{ Unstandardized Coefficients } & $\begin{array}{c}\text { Standardized } \\
\text { Coefficients } \\
\text { Beta }\end{array}$ & $\mathrm{t}$ & Sig. \\
\hline (Constant) & -3.866 & 4.672 & & -.828 & .410 \\
& Akuntabilitas (X1) & .580 & .230 & .165 & 2.524 & .013 \\
$1 \quad$ Transparansi (X2) & -.144 & .195 & -.059 & -.740 & .461 \\
& Responsif (X3) & 1.196 & .293 & .463 & 4.088 & .000 \\
& Partisipasi (X4) & .820 & .246 & .375 & 3.330 & .001 \\
a. Dependent Variable: Perencanaan TRK (Y1) & & & & \\
\hline
\end{tabular}

Berdasarkan hasil analisis yang dilakukan, maka persamaan regresi yang dihasilkan dalam penelitian ini adalah:

$Y=-3.866+0.580 X_{1}-0.144 X_{2}+1.196 X_{3}+0.820 X_{4}+e$

dimana:

$\mathrm{Y}=$ Perencanaan Tata Ruang Wilayah Kota

$\mathrm{X} 1=$ Akuntabilitas

$\mathrm{X} 2=$ Transparansi

$\mathrm{X} 3=$ Responsif

$\mathrm{X} 4=$ Partisipasi

Penjelasan dari model persamaan regresi tersebut dapat diterangkan sebagai berikut:

1. Konstansta sebesar - 3.866 menyatakan bahwa jika tidak ada akuntabilitas, transparansi, responsif dan partisipasi dalam perencanaan tata ruang kota, maka rencana tata ruang kota yang dihasilkan adalah - 3.866 .

2. Koefisien regresi $X_{1}$ (akuntabilitas) sebesar 0.580 menyatakan bahwa setiap penambahan 1 unit akuntabilitas akan meningkatkan bobot perencanaan tata ruang kota sebesar 0.580

3. Koefisien regresi $X_{2}$ (transparansi) sebesar - 0.144 menyatakan bahwa setiap pengurangan 1 unit transparansi akan mengurangi bobot perencanaan tata ruang kota sebesar -0.144

4. Koefisien regresi $X_{3}$ (responsif) sebesar 1.196 menyatakan bahwa setiap penambahan 1 unit responsibilitas akan meningkatkan bobot perencanaan tata ruang kota sebesar 1.196

5. Koefisien regresi $X_{4}$ (partisipasi) sebesar 0.820 menyatakan bahwa setiap penambahan 1 unit partisipasi akan meningkatkan bobot perencanaan tata ruang kota sebesar 0.820

Perencanaan tata ruang kota, sesungguhnya merupakan manifestasi dari konsep pengembangan wilayah yang di dalamnya memuat tujuan dan sasaran yang bersifat kewilayahan. Oleh karenanya, perencanaan tata ruang merupakan bagian tidak terpisahkan dari penataan ruang yang terdiri dari 3 proses utama yang saling berkaitan satu dengan lainnya, yakni: (1) Proses perencanaan tata ruang wilayah; (2) Proses pemanfaatan ruang; dan (3) Proses pengendalian pemanfaatan ruang (UU No. 
26/2007). Secara digramatik siklus tersebut dapat diketahui pada gambar berikut:

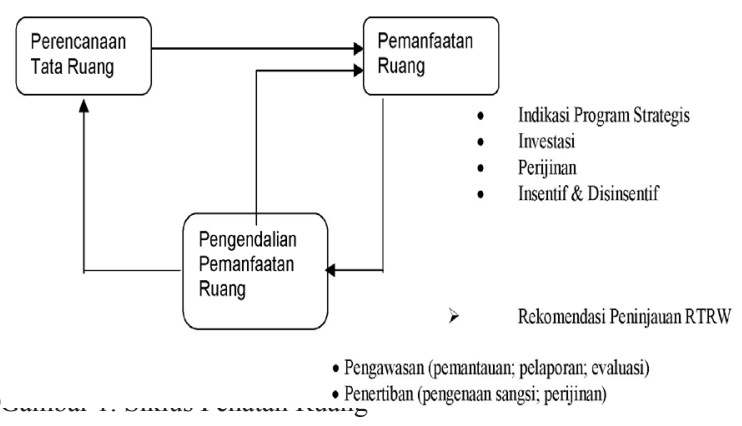

Dokumen Rencana Tata Ruang Wilayah (RTRW) pada hakekatnya merupakan suatu paket kebijakan umum pengembangan daerah sebagai bentuk intervensi kebijakan yang dilakukan agar interaksi manusia/makhluk hidup dengan lingkungannya dapat berjalan serasi, selaras, seimbang untuk tercapainya kesejahteraan manusia/makhluk hidup serta kelestarian lingkungan dan keberlanjutan pembangunan (development sustainability). Rencana tata ruang merupakan hasil perencanaan wujud struktural dan pola pemanfaatan ruang. Bagi wilayah Kota Metro, kebijakan yang dirumuskan pada dokumen ini merupakan dasar strategi pembangunan spasial, baik yang berkenaan dengan perencanaan tata ruang yang lebih terperinci (RDTRK, RTBL), maupun rencana kegiatan sektoral seperti kawasan perdagangan, industri, permukiman, serta fasilitas umum dan sosial. Dengan demikian, melalui instrumen perencanaan tata ruang diharapkan dapat mendorong pengembangan wilayah dalam rangka meningkatkan kualitas hidup masyarakat (city as engine of economic growth) yang berkeadilan sosial (social justice) dalam lingkungan hidup yang lestari (environmentaly sound) dan berkesinambungan (sustainability sound) dalam kerangka desentralisasi di tengah menguatnya arus demokratisasi dan globalisasi yang tengah melanda kehidupan masyarakat dewasa ini.

Dalam rangka mewujudkan kinerja pemerintahan yang baik (good government performance) dalam aktivitas perencanaan tata ruang, tentunya harus diawali dengan kebijakan yang baik (good policy), dan good policy hanya dapat dicapai melalui formulasi kebijakan yang balk (good policy formulation). Tanpa formulasi kebijakan yang baik tidak mungkin kebijakan yang baik akan terwujud, dan kinerja yang tinggi hanya dapat terwujud jika didukung oleh sistem dan proses pelaksanaan kebijakan yang baik. Diterapkannya prinsip governance dalam penyusunan tata ruang wilayah kota diharapkan akan menghasilkan produk rencana tata ruang yang tidak saja bersifat akomodatif dan legitimate. Akan tetapi juga diharapkan tidak menimbulkan persoalan dalam implementasinya dikemudian hari, karena keputusan yang dihasilkan tersebut merupakan kesepakatan bersama diantara para aktor dalam memanfaatkan ruang kota dalam kurun waktu 20 tahun mendatang. Pemahaman itu harus dicerminkan ke dalam pola dan struktur pemanfaatan ruang kawasan perkotaan. Penataan ruang kawasan perkotaan tidak semata-mata bermuatan alokasi fungsional dan fisik kawasan kota yang kaku, akan tetapi di dalamnya harus ada upaya untuk memberikan "jiwa dan identitas" pada kawasan perkotaan. Hal ini penting, mengingat bahwa ruang perkotaan tidak hanya diperuntukkan bagi kelompok yang mapan dan mampu ataupun sektor formal, akan tetapi juga perlu menampung usaha-usaha informal yang diberdayakan sehingga merupakan salah satu asset perkotaan. Oleh karena itu, dalam menata ruang perkotaan peluang kepada golongan ekonomi lemah harus mendapat tempat utama, agar dapat mengembangkan usahanya, meningkatkan produktivitasnya serta mengkaitkan usahanya dengan golongan ekonomi yang lebih kuat.

Dalam perspektif governance keterlibatan aktor di luar negara merupakan sebuah keniscayaan dalam rangka mengatasi berbagai persoalan publik. Aktor dimaksud adalah masyarakat, yang termasuk di dalamnya adalah sektor bisnis. Terkait dengan perencanaan ruang kota, sebagaimana dikemukakan oleh Dittmar \& Ohland (2004), terdapat dua kubu cara pandang dalam menata ruang kota, yaitu smart growth dan libertarian. Dalam era demokratisasi dan desentralisasi dewasa ini, paradigma libertarian yang menempatkan masyarakat sebagai aktor kunci dalam perencanaan kota memperoleh tempat yang signifikan. Oleh karenanya pendekatan perencanaan didorong untuk lebih mengedepankan demand masyarakat yang disebut sebagai community driven planning. Isu yang paling aktual untuk saat ini adalah bagaimana upaya untuk mencapai kondisi di mana masyarakat sendirilah yang mendesain rencana yang diinginkan dan pemerintah adalah fasilitatornya.

Sungguhpun demikian, dalam implementasinya artikulasi berbagai kepentingan masyarakat dalam perumusan kebijakan tidaklah semudah yang dibayangkan. Dari hasil penelitian diketahui, bahwa keterlibatan masyarakat dalam formulasi rencana tata ruang kota hanya terbatas pada pembahasan draft rencana yang sudah disusun oleh perencana untuk memperoleh persetujuan masyarakat dalam sebuah forum diskusi. Apa yang hendak dikemukakan, disini adalah bahwa "formalitas" partisipasi seolah-oleh telah dilaksanakan dalam penyusunan rencana tata ruang. Alasan yang dikemukakan selalu bersifat klise, bahwa kapasitas dan pemahaman masyarakat terhadap persoalan tata ruang sangat terbatas dan terkendala waktu (proyek) yang tersedia dalam penyusunan dokumen rencana tata ruang. Tidaklah berlebihan jika dikemukakan, bahwa hambatan dan tantangan terbesar dari penerapan perencanaan partisipatif adalah resistensi birokrasi (mental block) dan politisi, serta relatif masih terbatasnya kapasitas masyarakat baik teknis maupun terutama sikap/perilaku berdemokrasi. Resistensi birokrasi terutama berkaitan dengan pembagian/ pendelegasian kewenangan dan perimbangan keuangan. Sebagian besar birokrat masih keberatan apabila kewenangannya diserahkan yang akan membawa konsekuensi berkurangnya 
anggaran dinas/instansi yang dikuasainya. Selain itu, masih banyak peraturan birokrasi yang masih berorientasi "proyek". Pemberdayaan masyarakat dan pengembangan institusi local (kelembagaan partisipasi masyarkat) pun dilaksanakan dengan pendekatan proyek. Sedangkan keterbatasan kapasitas masyarakat, lebih sering merupakan resultan dari dominannya peran pemerintah (omnipotent) dalam mengelola berbagai persoalan publik yang telah berlangsung cukup lama, sehingga kreativitas dan kemandirian masyarakat belum mampu berkembang secara optimal.

\section{SIMPULAN}

Atas dasar uraian sebagaimana dijelaskan pada bagian pembahasan dalam rangka mengkaji pengaruh prinsip governance dalam perencanaan tata ruang kota, dapat disimpulan, bahwa terdapat hubungan dan pengaruh secara nyata dan signifikan antara prinsip governance yang meliputi akuntabilitas; transparansi; responsif dan partisipasi terhadap perencanaan tata ruang kota. Model regresi yang dihasilkan dapat digunakan sebagai prediktor perencanaan tata ruang kota daripada rata-rata perencanaan tata ruang kota itu sendiri.

Adapun saran dan implikasi kebijakan yang dapat direkomendasikan adalah, bahwa penerapan prinsip governance harus menjadi mindset para aparatur publik dalam mengatasi berbagai kepentingan dan persoalan publik di wilayah perkotaan. Selain itu dibutuhkan berbagai insentif kebijakan bagi operasionalisasi prinsip governance dalam mewujudkan good urban governance.

\section{DAFTAR PUSTAKA}

Akil, Sjarifuddin. 2001. "Penataan Ruang Dalam Rangka Mendorong Pengembangan Ekonomi Wilayah" Makalah Disampaikan pada Lokakarya Penataan Ruang Dalam Rangka Mendorong Pengembangan Ekonomi Wilayah Tangerang, 20 Juni.

Algifari, 2000. Analisis Regresi: Teori, Kasus dan Solusi. Edisi Kedua. Yogyakarta: Penerbit BPFE.

Bovaird, T. \& Loffler, E. (ed.), 2003, Public Management and Governance. London: Routledge.

Dardak, Hermanto. 2006. "Peran Penataan Ruang Dalam Mewujudkan Kota Berkelanjutan di Indonesia". Makalah pada Penyampaian "Penghargaan Pekerjaan Umum Bidang Penataan
Ruang” Semarang, 2 Mei.

Dittmar, Hank dan Ohland, Gloria. 2004. The New Transit Town: Best Practices in Transit-Oriented Development. Washington: Island Press.

Enserink, Bert and Koppenjan, Joop. 2007. "Public participation in China: sustainable urbanization ang governance", dalam Jurnal Management of Environmental Quality: An International Journal Vol. 18 No. 4

Friedman, J., 1987, Planning in The Public Domain, From Knowledge to Action, New Jersey: Princeton University Press.

Islamy, M. Irfan, 2003. Dasar-Dasar Administrasi Publik dan Manajemen Publik, Program Pascasarjana, Universitas Brawijaya Malang

Kartasasmita, Ginandjar. 1997. "Mewujudkan Penataan Ruang Yang Bertumpu Pada Kemitraan”, Makalah pada Seminar dan Kongres Nasional Ke V IAP, Jakarta, 10 Desember.

Lembaga Administrasi Negara (LAN), 2000. Akuntabilitas dan Good Governance, Jakarta: LAN.

Marshall, Julian D., 2007. Urban Land Area and Population Growth: A New Scaling Relationship for Metropolitan Expansion. Urban Studies, Vol. 44, No. 10, 1889-1904, September.

Pratikno, 2005. "Dari Good Governance Menuju Just dan Democrratic Governance". Makalah pada Seminar Nasional "Governance in Practices: Belajar Dari Pengalaman di Indonesia”, yang diselenggarakan oleh Panitia Dies Fisipol UGM Ke 49, 25 September.

Suzzetta, Paskah. 2006. Makalah Pada Seminar "Managing Change and Transition: from Good Governance to Sustainable Governance". Jakarta 16 Pebruari.

Thoha, Miftah, 2008. Ilmu Administrasi Publik Kontemporer, Jakarta: Kencana Prenada Media Group.

Undang-Undang No. 26 Tahun 2007 tentang Penataan Ruang

United Nations (UN). 2000. World Urbanization Prospects: The 1999 Revision, www.un/org/ esa/population/pubsarchive/urbanization/ urbanization.pdf). 